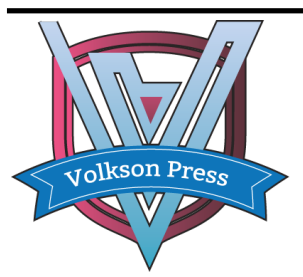

\title{
RESEARCH ON THE TEACHING METHOD OF INTEGRATING MOOC INTO TRADITIONAL CLASSROOM --- A CASE STUDY ON THE COLLEGE ENGLISH TEACHING IN CHINESE REGIONAL UNIVERSITIES
}

Hu Yixuan

Monash University, Melbourne, Australia.
*Corresponding Author Email: yixuanhu@qq.com

This is an open access article distributed under the Creative Commons Attribution License, which permits unrestricted use, distribution, and reproduction in any medium, provided the original work is properly cited

\section{ARTICLE DETAILS}

\section{Article History:}

Received 12 November 2017 Accepted 12 December 2017 Available online 1 January 2018

\section{ABSTRACT}

The proportion of students in regional universities is very high in China. To improve education quality and increase quantity of learners effectively, the author explores a method that is integrating MOOC (the new internet teaching method) with traditional teaching method in Chinese regional universities. The author first analyzes the characteristics of regional university learners based on geographical and social conditions, considering that the different characteristics result in different learning methods and preferences. After stating the current learning environment in Chinese regional universities and analyzing the features of both traditional classroom teaching and MOOC, this paper reveals that traditional teaching method alone is hard to satisfy learners' requirement, and visualaudio learning materials like MOOC facilitate learning better. Then the paper recommends Chinese regional universities to combine traditional classroom teaching with MOOC and puts forward some specific strategies for improving the integration, for example, increasing the MOOC proportion gradually, designing MOOC materials based on regional conditions and updating MOOC materials based on feedbacks.

\section{KEYWORDS}

Teaching model, MOOC, Learner characteristics, Learning promotion strategies

\section{INTRODUCTION}

In recent years, the development of information technology, especially the upgrading and transformation of Internet and mobile terminals, has greatly promoted the extension of time and space on teaching and learning, and diversified teaching methods. Massive Open Online Courses is known as "MOOC" or "MOOCs" for short, which is the successful case of Internet plus education. The emergence of MOOC has triggered an online learning wave around the world. Business establishments, venture capitalists, media and famous universities have joined the wave of MOOC, creating a large number of MOOC learning platforms. In 2012, some top universities in the United States set up a network learning platform to provide free courses on the Internet. Besides, three major course providers of Coursera, Udacity and edX rose in recent years and supplied students with the possibility of systematic online learning. In February 2013, National University of Singapore cooperated with the American company Coursera and contributed to this large open network course platform. Also, since 2012, many Chinese educational institutions followed the trend and involved in some world-famous MOOC platforms. At the same time, a number of Chinese local MOOC education platforms mushroomed, such as: MOOC中国, 学堂在线、中国大学MOOC、华文慕

课、好大学在线 and智慧树. Many Chinese national universities including Tsinghua University, Peking University, Shanghai Jiao Tong University and other famous institutions have taken the lead in building the MOOC platform and started to use it [1]. However, few regional universities adopt MOOC teaching models.

At present, many scholars have started to explore how to design a highquality MOOC, whose research mainly focus on mechanism in information processing and the strategy of reducing cognitive load under network learning environment. Besides, they study how MOOC could mix with other teaching methods such as "Flip Class" and explore the application of MOOC in some specific courses. This paper tries to explore the method to introduce MOOC to English learning of regional university.

\section{ANALYSIS OF THE CHARACTERISTICS OF THE LEARNERS IN REGIONAL UNIVERSITIES}

\subsection{The Demographic Characteristics of The Learners}

The proportion of regional universities in China is close to $90 \%$, and the enrollment test score is generally lower than that of national universities. There is a great difference among different regions in economic development and social environment. For example, economic and education system of northwest China is relatively underdeveloped compared to other regions. Because of lacking education, most people living in there are relatively conservative. On the contrary, the southeast coastal region gained rapid economic development in recent decades, people living in those areas are relatively rich and open-minded. These differences often lead to differences in learners' characteristics, hobbies, English levels, learning cognition and methods in English learning.

Simultaneously, there are great differences between urban and rural areas in China. Students from urban families and those from rural families also have differences in personality, learning styles, and learning psychology due to their different family education. Learners from urban families begin to learn English in a relatively young age (usually in primary school, grade two or even kindergarten), while learners from rural areas begin to learn English in a slightly older age (usually in secondary school). Therefore, they have fewer opportunities for English learning in primary school, and 
their English is relatively poor. In addition, family circumstance for example, whether students are the only one children in their families and gender of learners would affect their learning tendency, learning motivation and learning strategies.

\subsection{University English Learners' Learning Style}

Learning style is a very important element in learners' characteristics, which is stability and uniqueness. Up to now, the definition of learning style is controversial, and many researches understand it from different aspects. Some researchers believe that the definition of learning style is broader than that of cognitive style, which should include cognitive style, physiological and emotional factors [2]. Ehrman and Oxford hold that the learners' language learning style refers to the main tendency of learners to choose one learning approach when learning a new language [3].

University English course is a compulsory course for non-English Majors in China. The "College English curriculum requirements" makes specific requirements for English learning and practice of non-English Majors in Chinese universities from six aspects of listening comprehension, oral expression, reading comprehension, written expression, translation ability and recommended vocabulary.

Research on learners learning style is beneficial for educators to design and introduce appropriate teaching modes. The following are learning style factors of College English learners.

\subsubsection{Cognitive Elements Related to The Learner's Own Factors}

Students in the same school may have similar intelligence level but their way of thinking and cognition are different. For example, when reading a new article, some students tend to roughly read the whole article first, grasping the core idea and identifying the main structure, and then analyze some details like words and expressions in the article, which are difficult to understand in the rough reading. However, some students prefer to analyze the details first, then read the full article, understanding the core ideas and the whole structure.

\subsubsection{The Learner's Preference for Learning English}

For language learning, most students tend to choose visual and auditory learning resources. Video and image resources show learning contents intuitively [4]. Therefore, it is easily for learners to understand the learning content and improve learning efficiency. While, most universities employ traditional teaching mode currently and learners usually accept information passively, lacking independent critical thinking skills. Under this situation, most students are not satisfied and want to change the current teaching and learning mode.

\subsubsection{Strategies in The Process of Learning}

In the process of independent learning, university students usually use strategies to face their shortcomings correctly and make progress. Most of them would not only learn English in classroom, but also learn it regularly outside the class in a systematic and automatic way. They have their own learning strategies, plans and goals through the training of basic skills such as listening, speaking, reading, writing and translating. For example, some students tend to use network resources to help themselves improve their English learning effectively. Watching English movies can improve their listening and speaking skills and using some English learning network platform, they can find English tutoring courses or software to improve their writing skills.

\subsubsection{The Emotional Elements of Learning Style}

For different purposes, most university students have an interest in English learning and their motivation is rather high. Some students are interested in English, and eager to improve their English level. While some other learning English for passing exams, for example, CET4 (College English Test Band 4), CET6 (College English Test Band 6), postgraduate entrance examination, etc., and some students are learning for finding a good job in the future. However, in the process of English learning, some students have difficulties in English learning and do not have enough confidence. For those who are short of self-confidence, teachers should give appropriate emotional guidance to enhance their self-confidence and supply some strategies in English learning.

\subsubsection{Skills in The Learning Process}

Different learners have advantages and disadvantages in listening, speaking, reading, writing and translating. Therefore, teachers should teach and organize classroom activities in accordance with students' different levels and skills. To fulfill education individualized and improve the students' English ability, teachers should provide appropriate guidance to different learners.

\subsection{Influence of Learning Environment on The Learners}

Robert Gagne's information processing theory believes that information is processed differently at different stages, and learning events refers to events occurring at each information processing stage. Learning events are the process of the students' internal processing, and teaching is the external condition of arranging and controlling the learning by the teachers [5].

Learning environment is a significant element in both teaching and learning processes. It refers to the organic integration of the various learning conditions that can affect the development of learners' ability and their cognitive level. It contains various learning resources, aids, assessment, activities, strategies, learning and implementation sites, learning and implementation situations, interpersonal relationship and various participants in teaching process. To explore the effective method and support learners' learning through technology. The process and practice of learning are studied from the technical aspects based on learning theory.

It puts more emphases on the design and development of learning resources, learning process, learning tools, learning support system, etc. Developing good learning environment and promoting the information processing can improve the learning efficiency. In addition, learning in the real environment or virtual learning environment which is similar to the real can stimulate learners' enthusiasm and initiative to participate in interaction, thus improving learners' interest and efficiency in learning.

\subsection{The Learning Environment of Chinese Colleges and Universities}

In the context of Chinese high education system, learning environment includes elements such as the learning conditions, the distance between home and school, the time of study, the method to seeking help.

In China, most colleges and universities provide learners with good learning conditions. Almost all students have their own computers, and they can use the Internet at any time in the classroom, library, and dorm.

Also, most of them are full-time students. There are student apartments, canteens, and various stores on campus providing them with daily necessities and solving their daily life problems which ensures enough learning time for students.

\section{RESEARCH ON LEARNING PROMOTION STRATEGY}

\subsection{The characteristics of traditional classroom teaching}

Traditional classroom teaching has some remarkable characteristics, for example, teachers play the domain role in class and the main teaching method is teachers passing down knowledge according to the textbook. For students, the main classroom activity is taking notes and remember the textbook content. As is known to all, the core of education is to "learn", rather than "teach". While, traditional education emphasizes more "teaching" and "teacher centered" compared with "learning" [6].

\subsection{The Teaching Characteristics of MOOC}

MOOC is a new model of learning in the field of education. As a teaching mode that is different from traditional classroom teaching method, MOOC is based on learning science, which is a typical example of combining 
psychological laws with pedagogical practices. In terms of instructional design, MOOC comprehensively applied some theoretical principles of learning science, such as humanistic learning, mastery learning, constructivist learning, procedural teaching and meaningful learning, which have been advocated in recent decades [7].

As a new learning and teaching method, $\mathrm{MOOC}$ has various characteristics and advantages. Large scale, online and open are notable features of MOOC. Also, it is easy to use and inexpensive (most MOOCs are free), offering learning opportunities to almost all learners especially those who has financial problems. In other words, it provides people from all classes with rich and independent learning resources. Compared with the traditional educational activities which requires teachers and students to get together, MOOC breaks the limitation of time and space as a form of distance learning. Therefore, it is beneficial to individualized learning [8].

\subsection{Introduction of MOOC Teaching and Teaching Improvement Measures}

At present, some key universities in China, such as Tsinghua University, Peking University and Southeast University, begun to use MOOC platform. However, most regional universities haven't started yet. In view of the advantages of MOOC, regional universities could try to combine traditional teaching with MOOC [9]. For example, MOOC could be an assisted teaching method to facilitate classroom teaching. The combination of traditional teaching method and MOOC should be improved from the following aspects when implemented by regional universities in China.

\subsubsection{Increase the Proportion of MOOC Gradually}

Because as a new teaching mode, MOOC has rarely been used in regional universities and its effect needs to be tested. Therefore, in the early stage of introduction, teachers can apply MOOC to some certain sections of the course. Specifically, they can select some chapters that are easier for selfdirected learning, or MOOC can be used to facilitate some skills, such as speaking and listening. If the use of MOOC brings good learning outcomes and learners can adapt to this new teaching mode. Educator can consider increasing the use of MOOC gradually.

\subsubsection{Design and Make MOOC Based on Local Conditions}

At present, most of the MOOC courses are made by teachers working in key universities in China, such as Tsinghua University and Peking University. Therefore, when using MOOC, regional universities should combine local characteristics with MOOC [10]. For example, they should adjust or choose the course content, exercises, test questions according to local learners and other factors. Unlike traditional teaching modes, MOOC provides technical support and communication platform for the communication not only between learners and instructors, but also between learners and learners. This helps the learners to fully understand the knowledge they learn, and to improve the value of the MOOC resources.

\subsubsection{Updating MOOC Resources in Time Using Feedback}

Collecting feedback after class from students can not only increase students' attention to the curriculum, but also help teachers to perceive teaching contents from a student's perspective. Teachers can instruct from a more understandable perspective, and intrigue students' interest in target knowledge. Therefore, teachers should investigate the learners' opinion and collect their feedback on the course in time. Also, teachers should adjust their teaching modes and MOOC course resources according to the feedback information, so that learners can accept knowledge easily and effectively [11].

\section{SETTING UP APPROPRIATE COURSE ASSESSMENT METHODS}

In order to improve the students' self-directed learning ability using MOOC, the results of MOOC assessment can be counted into the final grades. If MOOC teaching has a good effect, we can gradually increase the proportion of MOOC examination results in the final grade.

\section{CONCLUSION}

At present, Chinese college and university offer College English courses only to freshmen and sophomores. But most students think the learning effect was not as good as expected. Even worse, some students thought that the English learning in the first two years of the University didn't improve their English level at all. One of the reason is that the traditional English teaching mode makes students lose interest in learning. The introduction of MOOC to English teaching and learning and using multimedia technology to provide English learning resources increase the interest of learning and improve the learning effect.

\section{ABOUT THE AUTHORS}

Hu Yixuan is a master student with the School of Education of Monash University, Melbourne, Australia. Her research interests include English teaching and Education theory. (email: yixuanhu@qq.com)

\section{REFERENCES}

[1] Shen, M. 2015. The analysis and suggestion of MOOC current application situation. Software Guide, (6), 56-57. doi: 10.16735/j.cnki.jet.2015.06.004

[2] Lin, L. 2009. The research of learning style in the mode of foreign language network independent learning. China Education Info, (2), 66-70.

[3] Ehrman, M., Oxford, R. 1995. Cognition Plus: Correlates of Language Learning Success. Modern Language Journal, 79 (1), 67-89.

[4] Cai, L., Wei, L. 2015. The importance of foreign language teaching complying with the students' learning style. English square, (10), 101-102. DOI: $10.16723 /$ j.cnki.yygc.2015.10.054

[5] Ilie, M.D. 2014. An adaption of gagné's instructional model to increase the teaching effectiveness in the classroom: the impact in romanian universities. Educational Technology Research and Development, 62 (6), 767-794. https://doi.org/10.1007/s11423-014-9353-6

[6] Zhang, F. 2007. The enlightenment of the "student-centered" education concept in the United States -- and the transition from "teacher-centered" to "student-centered". Journal of South China University of Technology (Social Science Edition), 9 (2), 68-72. doi: 10.19366/j.cnki.1009055x.2007.02.015

[7] Yang, X., Wang, D., Wang, Y., Bai, G., Hong, W., Xia, H. 2017. Exploring the Method of Constructing Active Class Complementary to MOOC. Modern Educational Technology, 27 (1), 115-120. doi 10.3969/j.issn.10098097.2017.01.017

[8] Sun, Z. 2017. The teaching advantages and characteristics of perfect MOOC. Industry and Information Technology Education, (7), 1-6.

[9] Tian, B., Chen, Z., Dai, L., Xie, Y., Qiu, Y. 2016. Application of MOOC in China and Foreign MBA Education. Higher Education Review, 1 (4),160177.

[10] Zhang, W., Wang, H. 2014. MOOC Course Learning Experience and Its Indigenization Enlightenment. Modern Distance Education, (4), 3-9. doi: $10.13927 /$ j.cnki.yuan.2014.0038

[11] Wang, H., Ruan, S., Zhang, Z. 2015. Characteristic analysis of MOOC teaching evaluation in big data background. Primary and Middle School Educational Technology, (10), 19-23. 